\title{
正常歩行の下肢衝撃吸収機構における 足関節機能の検討
}

\author{
Ankle Joint Function in the Lower Limb Impact Absorption Mechanism \\ of Normal Gait
}

古谷 友希 ${ }^{1,2)}$ 柊 幸伸 ${ }^{3)}$

TомоIкI FURUYA, RPT, MS ${ }^{1,2)}$, YUKINOBU HIIRAGI, RPT, PhD ${ }^{3)}$

1) Department of Physical Therapy, Medical Academy: 1-18-1 Nakadaimotomachi, Kawagoe-shi, Saitama 350-1138, Japan TEL +81 49-245-68523 E-mail: t.furuya@iapt.jp

2) Division of Physical Therapy, Department of Health Science, Graduate School of International University of Health and Welfare

3) Department of Physical Therapy, Faculty of Health Sciences, Ryotokuji University

Rigakuryoho Kagaku 32(6): 835-838, 2017. Submitted May 29, 2017. Accepted Jul. 22, 2017.

\begin{abstract}
Purpose] We aimed to clarify the main part where shock absorption is carried out by using an acceleration sensor. [Subjects and Methods] The subjects were eleven healthy male subjects, average age, 20.8 \pm 2.44 years old. Acceleration was measured with sensors attached to the calcaneus, fibula and lateral part of the thigh, and the statistical significance of differences was examined using the Friedman test (Tukey's method). [Results] Acceleration (deg/sec/BW/WS) at the calcaneus, femoral head and thigh were 4.2 $\pm 1.2,0.2 \pm 0.03,0.1 \pm$ 0.06 , respectively. RMS $\left(\mathrm{m} / \mathrm{s}^{2} \mathrm{rms} / \mathrm{WS}^{2}\right)$ of the same sites were $68.7 \pm 20.9,5.4 \pm 0.8$, and $3.7 \pm 1.6$, respectively. There were significant differences $(\mathrm{p}<0.01)$ between the accelerations at the calcaneus and the fibula portion, and between the accelerations at the calcaneus and the femoral region. There was no significant difference between the accelerations at the fibula and the thigh. There were significant differences between the RMS values at the calcaneus and the fibular head $(p<0.05)$, and between the RMS values at the calcaneus and the thigh $(\mathrm{p}<0.01)$. There was no significant difference between the RMS values at the fibula head and the thigh. [Conclusion] The results show that the impact during normal gait is mainly absorbed by the ankle joint.
\end{abstract}

Key words: normal gait, impact absorption, acceleration sensor

要旨:〔目的〕加速度センサを使用し，衝撃吸収が行われる主な部位を明らかにすることを目的とした。〔対象と方法〕 対象者は男性 11 名, 平均 $20.8 \pm 2.44$ 歳の健常者を実験対象とした。踵骨部, 腓骨部, 大腿外側部の合計 3 台のセン サからデータを集積し, Friedman 検定（Tukeyの方法）を用いて統計的有意差を検討した。〔結果〕踵骨部, 腓骨頭部, 大腿部での加速度 $(\mathrm{deg} / \mathrm{sec} / \mathrm{BW} / \mathrm{WS})$ はそれぞれ $4.2 \pm 1.2,0.2 \pm 0.03,0.1 \pm 0.06$ だった。同様の部位の RMS (m/ $\left.\mathrm{s}^{2} \mathrm{rms} / \mathrm{WS}^{2}\right)$ はそれぞれ $68.7 \pm 20.9,5.4 \pm 0.8,3.7 \pm 1.6$ だった。踵骨部での加速度と腓骨部での加速度, 踵骨部 での加速度と大腿部での加速度の間において有意に差があった（p<0.01）. 腓骨部での加速度と大腿部での加速度 の間に有意な差はなかった，踵骨部での RMS 值と腓骨頭部での RMS 值の間において有意に差があった（p<0.05）, 踵骨部での RMS 值と大腿部での RMS 值の間において有意に差があった（p<0.01）。腓骨頭部での RMS 值と大腿部 での RMS 值の間に有意な差はなかった。〔結語〕正常歩行中の衝撃は足関節で多く吸収されていることが判明した。 キ一ワード：正常歩行, 衝撃吸収, 加速度センサ

\footnotetext{
1) 専門学校医学アカデミー 理学療法学科：埼玉県川越市中台本町 1丁目 18 番地 1 (テ 350-1138) TEL 049-245-68523

2) 国際医療福祉大学大学院 保健医療学専攻 理学療法学分野

3) 了德寺大学 健康科学部 理学療法学科
} 


\section{I.はじめに}

理学療法の分野で対象者の歩行を分析することは日常 的なものである。昨今では伝統的な歩行周期 11 や Perry ${ }^{2}$ によっって分類された歩行周期が広く使われてい る。後者には歩行中の衝撃吸収や身体重心の円滑な前方 移動になど関わる機構（ロッカー機能）の存在が示され ている.

ロッカー機能には, (1)ヒールロッカー, (2)アンクル ロッカー，(3)フォアフットロッカーがある。この中の ヒールロッカーは初期接地直後から荷重応答期に起こる 戦略である. 正常歩行では初期接地からわずか 0.02 秒 の後に身体重量の約 $60 \%$ が接地脚に加重されるといわ れて抢り 2), 荷重応答期に行われるヒールロッカーの機 能的意義は衝撃吸収の意味合いが強いと筆者は考えて いる.

また，膝関節の衝撃吸収機構を重要視した論文は多く あるものの 1,4,7)，定説的に重要性を述べている．各関節 の衝撃吸収の程度に関する具体的な検討がなされている 報告には，1995 年の報告 ${ }^{5)}$ があり，その中では足関節 の機能的役割の重要性が検討されている。しかし, 純粋 な正常歩行（裸足）での検討報告は筆者が渉編した限り では見当たらない。この報告でも使用されているような 加速度センサは工学分野ではすでに多用されており, 理 学療法分野でも類似したセンサを利用した報告を散見す るようになった 6,7)。今回，加速度センサを使用し，正 常歩行（荷重応答期）に扔ける，踵部抢よび腓骨部，腓 骨部および大腿部で得られた最大加速度の差を検討する ことで, 荷重応答期に衝撃吸収が行われる主な部位を明 らかにすることを目的とする。

\section{II. 対象と方法}

\section{1. 対象}

対象者は専門学校に通う男性 11 名, 平均年齢 20.8 歳 （土2.4：SD）で, 被験者参加希望の意思表示があった 者のみを対象としている. 対象者には研究の趣旨を口頭 および書面にて十分に説明し，同意書にサインをした者 で，全身に特別な疾患がない者のみ実験対象とした，対 象者の属性を表 1 に示す。本研究は国際医療福祉大学大 学院の倫理審査委員会の承認（承認番号 14-Ig-74）を受

\section{表 1 対象者の属性}

\begin{tabular}{lr}
\hline 年齢 $($ 歳 $)$ & $20.8 \pm 2.4$ \\
体重 $(\mathrm{kg})$ & $68.2 \pm 10.3$ \\
身長 $(\mathrm{cm})$ & $168.6 \pm 4.2$ \\
下腿長 $(\mathrm{cm})$ & $40.1 \pm 1.8$ \\
足長 $(\mathrm{cm})$ & $25.1 \pm 1.1$ \\
\hline
\end{tabular}

平均值 \pm 標準偏差.
け実施した。

\section{2. 方法}

測定には 8ch Wireless Motion Recorder (MVP-RF8GC500，マイクロストーン社製）を使用し，大腿外側部 （膝関節裂隙から近位方向へ $7.5 \mathrm{~cm}$ の部分）および，腓 骨頭部に粘着テープおよびバンドで装着し，それぞれ大 腿部，腓骨頭部の加速度を測定した。さらに 1 台の MVP-RF8-GC500を用意し, 機器の外部接続端子に小 型の 6 軸 Motion Recorder（MP-M6-02/500C, マイクロ ストーン社製）と2つのクリックスイッチ（BP-R，東 京センサ社製）を接続した。MP-M6-02/500C は，踵骨 後面に粘着テープで固定し, 踵骨部の加速度を測定に使 用した。クリックスイッチは足底の踵部と母趾に貼付し フットスイッチとして使用した（以下 FS）。この MVPRF8-GC500 は内蔵するセンサの機能は使用せず，外部 接続した MP-M6-02/500C と FS の計測データのトラン スミッターとして使用した。 以上合計 3 台の MVP-RF8GC500 は Bluetooth によりパーソナルコンピューターに 接続され，サンプリング周期 $1 \mathrm{msec}$ で計測データを集 積した（図 1).

集積したデータから歩行周期の $12 \%$ を荷重応答期と して抽出した，衝撃を定量化するにあたり，踵接地時に， 踵が床面に衝突した力の反力として発生した最大加速度 をセンサの $\mathrm{Y}$ 軸（上向き）で捉え，踵接地時の衝撃加 速度とした。そこから得られた 3 回分の測定デー夕を平

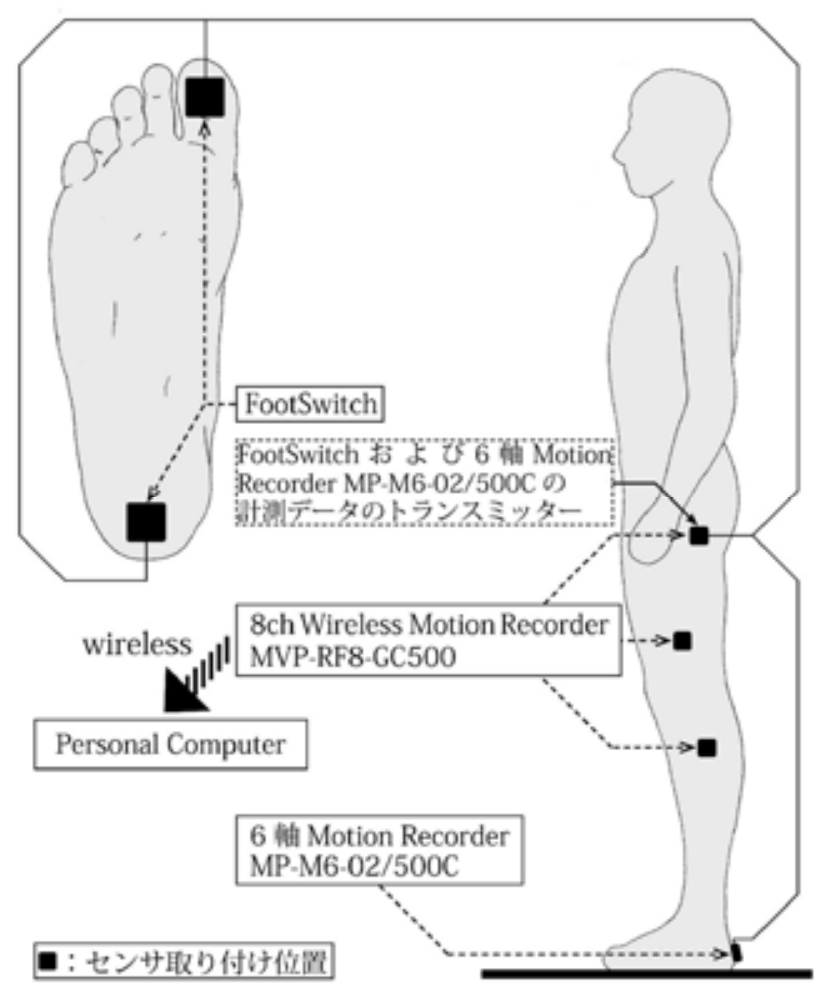

図1センサ取り付け位置 
均化し, 代表值として採用した。この最大加速度は体重 と歩行速度とで除すことで正規化した。 また，加速度は その収束までに僅かに時間がかかる。 よって, 測定時間 内に発生した加速度の大きさそのものを定量化する手法 として，Y 軸（上下方向）の RMS（Root Mean Square) 值を算出した.Menz ら ${ }^{8)}$ は若年者と高齢者を対象に歩 行の安定性を評価比較検討している。 その実験では, 得 られた RMS 值を歩行の安定規範とし, その值は歩行速 度から指数関数的に影響を受けていることを報告してい る. 本実験では快適速度での歩行で実験を行っており, 歩行速度の影響を除くために歩行速度の 2 乗で除すこと で正規化した，加速度のサンプルは $14 \mathrm{~m}$ (前後 $2 \mathrm{~m}$ 予 備区間, 中央 $10 \mathrm{~m}$ 測定区間）の歩行を 3 回行い, デー 夕は歩き初めと歩き終わりの影響を最も受けないと思わ れる, 歩行区間の中央 $5 \mathrm{~m}$ 地点付近のデー夕を採用 した。

統計処理は Free JSTAT version13.0を使用した。踵部, 腓骨頭部，大腿部の各最大加速度の值を体重と歩行速度 で正規化した值，また，RMS 值の各部位間に抢ける統 計的有意差について Friedman 検定（Tukeyの方法）を 用いて検討した。 パラメトリック検定を行う際に望まし いサンプル数は $\mathrm{n}=20 \sim 25$ 以上とされているが, 本研 究でのサンプル数は 11 ケースと少ない. よって, ノン パラメトリック検定である Friedman 検を採用した ${ }^{10)}$.
III. 結 果

踵骨部と腓骨部での加速度, 踵骨部と大腿部での加速 度の間に扔いて有意差があった $(\mathrm{p}<0.01)$ ．腓骨部と大 腿部での加速度の間に有意差はなかった，踵骨部と腓骨 頭部での RMS 值の間に扔いて有意差があった（p< 0.05)，踵骨部と大腿部での RMS 值の間において有意 差があった $(\mathrm{p}<0.01)$. 腓骨頭部と大腿部での RMS 值 の間に有意差はなかった。

踵骨部, 腓骨頭部，大腿部での最大加速度を表 2 に示 す. 踵骨部, 腓骨頭部, 大腿部での RMS 值を表3に示す.

\section{IV. 考 察}

踵骨部と腓骨頭部, 腓骨頭部と大腿部での垂直方向へ の最大加速度の值揖よびRMS 值で統計的有意差が認め られた。腓骨頭部と大腿部の間では統計的有意差が認め られなかったことから, 初期接地後に接地面から受けた 衝撃は足関節で効果的に吸収されていることがわかっ た。また，この結果は，田川ら5)が報告する健常成人 の自由歩行で実験を行った結果に類似して抄り, 概敉妥 当な結果であると考えている.

このような結果となった理由としては, 歩行は下位に 位置する慣性のより小さい部位が接地時に衝撃力に素早 く応答し, より上位にはほぼ一定の衝撃加速度を伝播す る様式になっているという報告5)があることから，本

表 2 各部位における最大加速度

\begin{tabular}{cccc}
\hline & 踵骨部 \pm 標準偏差 & 腓骨頭部 \pm 標準偏差 & 大腿部 \pm 標準偏差 \\
\hline $\begin{array}{c}\text { 最大加速度 } \\
\left(\mathrm{m} / \mathrm{sec}^{2} / \mathrm{BW} / \mathrm{WS}\right)\end{array}$ & $4.2 \pm 1.2$ & $0.2 \pm 0.03$ & $0.1 \pm 0.06$ \\
\hline \hline 踵骨部 \pm 標準偏差 & - & $* *$ & $* *$ \\
\hline 腓骨頭部 \pm 標準偏差 & $* *$ & - & n.s. \\
\hline 大腿部 \pm 標準偏差 & $* *$ & n.s. & - \\
\hline $\mathrm{n}=11$. & $* *: \mathrm{p}<0.01$. \\
$\mathrm{BW}:$ body weight, WS : walking speed, & n.s. : not significant. &
\end{tabular}

表 3

各部位における Root Mean Square 值

\begin{tabular}{cccc}
\hline & 踵骨部 \pm 標準偏差 & 腓骨頭部 \pm 標準偏差 & 大腿部 \pm 標準偏差 \\
\hline $\begin{array}{c}\text { Root Mean Square 值 } \\
\left(\mathrm{m} / \mathrm{s}^{2} \mathrm{rms} / \mathrm{WS}^{2}\right)\end{array}$ & $68.7 \pm 20.9$ & $5.4 \pm 0.9$ & $3.7 \pm 1.6$ \\
\hline \hline 踵骨部 \pm 標準偏差 & - & $*$ & $* *$ \\
\hline 腓骨頭部 \pm 標準偏差 & $*$ & - & n.s. \\
\hline 大腿部 \pm 標準偏差 & $* *$ & n.s. & - \\
\hline $\mathrm{n}=11 . * *: \mathrm{p}<0.05$, & $* *: \mathrm{p}<0.01$. & & \\
WS : walking speed, n.s. : not significant. & &
\end{tabular}


研究で行った実験でも, 前述の様式が働くことで, 足関 節が大きく衝撃を吸収したと考える。しかし，同じ報告 の中では, その様式が働く条件として, 膝関節が踵接地 時にある程度の伸転位に保たれていることを挙げてい る、つまり, 今回の実験結果が従来の報告と異なる結果 になった原因は, サンプルを集積した母集団の歩行時の 膝関節可動域に関係があるのではと考えている，本研究 は正常歩行の分析であり, 前述の通り得られた結果とし ては妥当なものであると考えているが, この原因追求に ついては今後の課題としたい.

木藤ら 9) は変形性膝関節症患者 (OA 患者) の歩行分 析で, 膝関節部に異常な側方加速度パワースペクトルを 認めており，その原因の一つに衝撃吸収機構の破綻を挙 げている。衝撃吸収機構に対する理学療法治療介入では 膝関節の伸筋である大腿四頭筋への筋力増強訓練が多く 行われている印象がある11)。一方で, 本研究の結果で は足関節で衝撃吸収がなされている結果となった。つま り，下肢関節による衝撃吸収という観点では，足関節機 能に着目した理学療法治療介入が重要になってくるので はと考えている。

先行研究に類似した結果が出ているものの, 本研究の サンプル数は 11 名と少なく, 今後サンプル数を増やす 必要があると考えている。 また，今日の加速度センサは， 無線化, 小型化がなされ, 動作分析の検査精度の向上に 寄与してきた。しかし, 本研究で踵骨部に使用したセン サは小型で軽量だが，丸みをおび，可動性に富む踵部後 面には設置が難しく，また足関節の底背屈時に起こるセ ンサケーブルのたわみに影響され，センサ自体の角度が 変化してしまう。このことから, 踵骨部で得られたデー 夕の標準偏差は大きくなってしまったと考えている。サ ンプル数の少なさ, センサケーブルのたわみによる測定
誤差といった留意すべき点があり，臨床応用には精査が 必要であるが, 一定の知見を得ることができた。

\section{引用文献}

1) 中村隆一, 齋藤 宏, 長崎 浩: 基礎運動学, 第 6 版. 医 歯薬出版, 東京, 2003, pp361-377.

2) Perry J:ペリー歩行分析 正常歩行と異常歩行. 武田 功· 他 (監訳), 医歯薬出版, 東京, $2007, \mathrm{p} 21$.

3) Götz-Neumann K: 観察による歩行分析. 月城慶一·他 (監訳), 医学書院, 東京, 2006, pp35-36.

4) 山本澄子：脳血管障害の歩行分析. 理学療法科学, 2002, 17: $3-10$.

5) 田川善彦, 山本耕之, 松尾重明・他：ヒトの足接地時に 扣ける人体への衝撃力の評価. 日本機械学会論文集 $\mathrm{C}$ 編, 1995, 61: 3859-3865.

6) 柊 幸伸, 加藤宗規, 佐藤 仁·他： 3 軸角速度センサを用 いた動作分析の試み. 理学療法科学, 2005, 20: 93-98.

7) 大西智也, 橘浩 久, 武田 功: 加速度・角速度センサに よる立位時の骨盤の動きの検討. 理学療法科学, 2014, 29: 595-598.

8) Menz HB, Lord SR, Fitzpatrick RC: Age-related differences in walking stability. Age Ageing, 2003, 32: 137-142.

9) 木藤伸宏, 島澤真一, 弓削千文・他：加速度センサを用い た変形性膝関節症の歩行時下腿運動の解析（2002年度研究 助成論文). 理学療法学, 2004, 31: 86-94.

10) 日高正巳：よくわかる研究法 13 , 対象者をどうやって選ぶ か? デー夕を取る方法の問題を考えてみよう. 理学療法学, 2011, 28: 502.

11) 市橋則明, 大畑光司, 才藤栄一：変形性膝関節症に対する 筋力トレーニング再考 (第一分科会『変形性膝関節症の最新 の評価と治療』)。第35 回日本理学療法士協会全国研修会特 集号 (テーマ: 理学療法に扔ける最新の評価と治療). 理学 療法学, 2001, 28: 76-81. 